\title{
Direct Methods for Detecting Picorna-like Virus from Dead and Alive Triatomine Insects
}

\author{
GS Rozas Dennis/ ${ }^{+}$, JL La Torre*, OA Muscio*, DMA Guérin**
}

Centro de Recursos Renovables de la Zona Semiárida, Edificio E3 Complejo de la Carrindanga, Florida 4000, (8000) Bahía Blanca, Argentina *Centro de Virología Animal, Serrano 665, (1414) Buenos Aires, Argentina **Departamento de Física, Universidad Nacional del Sur, Avda. Alem 1253, (8000) Bahía Blanca, Argentina

In this work we report four different destructive and non-destructive methods for detecting picornalike virus particles in triatomines. The methods are based on direct observation under transmission electron microscope and they consist of four ways to prepare samples of presumable infected material. The samples are prepared processing dead or alive insect parts, or even dry or fresh insect feces. The methods can be used as analytical or preparative techniques, for quantifying virus infection and checking virus integrity as well. In this work the four methods are applied in order to detect Triatoma virus $(\operatorname{Tr} V)$ particles in $\mathrm{T}$. infestans colonies.

Key words: picorna-like virus - Triatoma virus - Triatoma infestans - transmission electron microscope methods

Insect viruses have been studied for many years, due to the interest in the study of diseases of invertebrates and, more recently, because of their potential use as pest management agents (Evans 1986).

Isolation of viruses from the host is an essential step for diagnosis or for specific purposes requiring a high degree of purity. Early techniques for the study of insect viruses were based on the recognition of symptoms and the use of electron microscopy makes the identification of various virus groups possible. Since the 1960s, the development of sophisticated biochemical and molecular techniques has opened the way for a more detailed taxonomy and the prospect of relatively rapid and accurate methods of diagnosis (Evans \& Shapiro 1997). In this work four methods for the direct identification of viral particles among wild and/or laboratory colonies of triatomines are proposed. For more detailed isolation techniques, Tompkins (1991) provides a useful and comprehensive set of references to these methodologies.

Chagas disease is caused by the infection of the protozoan Trypanosoma cruzi, and triatomines commonly named as "kissing bugs" are the main vectors of this parasite. According to the latest epidemiological data, about 55 million people are at risk of become infected (WHO 1999), in Southern Cone Countries (Argentina, Bolivia, Brazil, Chile, Paraguay and Uruguay).

\footnotetext{
${ }^{+}$Corresponding author. Fax: +54-921-452.1942.

E-mail: grozas@criba.edu.ar

Received 8 April 1999

Accepted 21 December 1999
}

Triatoma infestans is the most domestic of the triatomines, adapted to human dwellings and it is the main vector of $T$. cruzi in extensive areas of Argentina, Uruguay, Chile, Bolivia, Paraguay, Brazil and Southern Peru (Zeledón \& Rabinovich 1981, Schofield \& Dolling 1992).

Studies of viral pathogens in this species made the identification of Triatoma virus (TrV) possible (Muscio et al. 1988) and its potential use as a biological control was suggested (Muscio et al. 1997). $\mathrm{TrV}$ was isolated from T. infestans and its biochemical and biophysical properties were investigated (Muscio et al. 1987, Muscio 1988). TrV particles are non-enveloped and have $30 \mathrm{~nm}$ in diameter, the sedimentation coefficient is of about $165 \mathrm{~S}$ and the buoyant density in $\mathrm{CsCl}$ is $1.39 \mathrm{~g} / \mathrm{ml}$. The viral genome contains a single stranded RNA molecule with a molecular weight of $3 \times 10^{6} \mathrm{Da}$. The capsid is composed of three major and minor structural polypeptides, VP1, $-2,-3$ and VP0 respectively. All these data have justified the classification of $\operatorname{TrV}$ as a putative member of the familiy Picornaviridae (Muscio et al. 1988) in which insect viruses such as Cricket paralysis (CrPv), Drosophila C (DCV), Gonometa (Matthews 1982) and Ropalosiphum padi (Moore et al. 1987) have already been placed.

$\mathrm{TrV}$ replicates within the cytoplasm of gut cells of triatomines (Muscio 1988). Some of the reported pathological effects of this virus were a high mortality rate, delayed development as a result of the affection of molting process and an important reduction in the fecundity (Muscio et al. 1997, Rozas Dennis et al. 1997a,b, Rozas Dennis \& Cazzaniga 1997).

The host range for $\mathrm{TrV}$ includes T. Infestans; T. platensis; T. delpontei, T. pallidipennis, T. 
rubrovaria and Rodinius prolixus reported by Muscio (1988), and T. guasayana and T. patagonica reported by Rozas Dennis (1997b) and Rozas Dennis and Cazzaniga (1997) respectively.

Both transovarial and horizontal mechanisms are involved in the transmission of $\mathrm{TrV}$. The former one would be of great importance for the spread of $\mathrm{TrV}$ among field populations and the latter one for the virus dissemination in laboratories and insectaries under rearing conditions (Muscio et al. 1997). Coprophagy and cannibalism are modes of behaviour reported among triatomines in insectaries and they are the principal ways of introducing parasites such as Blastocrithidia triatomae into these bug populations (Schaub et al. 1989). These two horizontal transmission mechanisms would also account for virus infection (Muscio et al. 1997). Therefore, it is necessary to check continuously insect colonies in order to detect early $\mathrm{TrV}$ infection.

In this work, two destructive and two non-destructive methods for picorna-like viral particles detection under transmission electron microscope (TEM) observation are reported. The methods consist of four ways to prepare samples of presumable infected material.

\section{MATERIALS AND METHODS}

The material consisted of insects from fourth (NIV) and fifth (NV) nymphal instars and females of $T$. infestans. All the insects were from colonies infected with $\mathrm{TrV}$, in which mortality and other infection aspects were studied (results will be published elsewhere).

In the four methods described below, observations under TEM were carried out according to the following procedure: a drop of the sample was deposited on top of formvar grides, 200 mesh, negatively stained with 3\% uranyl acetate and finally observed under TEM (Joel 190 CX, Tokyo, Japan). Buffer solution was NMT (0.01 M-Cl Na, $0.001 \mathrm{M}-\mathrm{Cl} \mathrm{Mg} 0.05 \mathrm{M}$ - Tris Hcl, pH 7.5).

Method 1 - Whole bodies of frozen dead insects $\left(-18^{\circ} \mathrm{C}\right)$ were macerated in $10 \mathrm{ml}$ NMT buffer. The homogenate was filtered and chloroform was then added (1:1, buffer:chloroform). A first centrifugation at $6,500 \mathrm{x}$ g for $20 \mathrm{~min}$ was done. The pellet was discarded and the supernatant was centrifugated at $51,000 \mathrm{x}$ g for $150 \mathrm{~min}$. The supernatant obtained was discarded and the pellet resuspended in one $\mathrm{ml}$ of NMT buffer with N-Lauryl Sarcosine 1\% (Pharmacia). This suspension was layered on top of a $30 \mathrm{ml} 10-30 \%$ sucrose gradient prepared in the same buffer, and centrifugation at $104,000 \mathrm{x} \mathrm{g}$ for $150 \mathrm{~min}$ at $4^{\circ} \mathrm{C}$ was carried out. The gradient was fractionated while measuring OD 280 . In order to extract sucrose, fractions contain- ing virus were dialyzed overnight against NMT buffer. A drop of the final virus solution was observed under TEM. This method is similar to that one reported by Muscio et al. (1988), when $\operatorname{TrV}$ was first described.

Method 2 - The material used consisted only of the fresh abdominal contents of sacrificed insects. The abdominal contents were dissolved in $0.5 \mathrm{ml} \mathrm{NMT}$ buffer and centrifuged at $10,000 \mathrm{x} \mathrm{g}$ for $5 \mathrm{~min}$. A drop of the supernatant was observed under TEM.

Method 3 - The sample consisted of fresh feces from alive insects. An abdominal compression was done to each individual by means of tweezers and two to four drops of feces were introduced in 0.5 $\mathrm{ml}$ NMT buffer and microcentrifugated at 10,000 $\mathrm{x} g$ for $5 \mathrm{~min}$. A drop of the supernatant was observed under TEM.

Method 4 - The sample consisted of "buttons" of dry feces fixed to the paper fans inside the insects rearing containers. Five buttons were dissolved in $0.5-1 \mathrm{ml}$ of NMT buffer and then microcentrifugated at 10,000 $\mathrm{x}$ g for $5 \mathrm{~min}$. A drop of the supernatant was observed under TEM.

\section{RESULTS AND DISCUSSION}

In most cases the basis for identification of viral pathogens is the availability of insects showing symptoms of infection (Evans \& Shapiro 1997). After the insect pathogen is identified and the purification protocol carried out, purified or semi-purified virus can be placed directly onto formvar or other grids and layered with carbon for examination under TEM without further treatment (detailed protocols for preparation of specimens for electron microscopy with either positive or negative staining are provided by Adams \& Bonami 1991).

Studies of virus infection and virus dynamic in laboratory and/or wild colonies require different methods of detection and quantification of the virus content. Large amounts of infected material are generally neccesary to isolate virions from dead or alive insects, or, depending on the insect size, different numbers of individuals have to be processed.

In this work, four methods to test the presence of $\mathrm{TrV}$ particles in infected $T$. infestans bugs using stained samples observed under TEM are reported. The methods are based on the way the samples are prepared. In method 1, the samples are drops of high purified virus obtained from the dead frozen insects (see Materials and Methods). TEM observation of purified material is the usual way to test particle integrity after a complete purification and concentration procedure. In Fig. 1 viral particles obtained from ten female dead insects are shown. Since analitical purification can be used as a 
method for quantifying the infection degree of an insect colony (i.e.: by comparing the resultant viral amount with the weight of the purified insects), method 1 provides a way to compare the equivalence of different purifications.

In method 2, the sample is prepared with the whole gut contents of sacrificed insects. In Fig. 2 virus obtained from five $\mathrm{NV}$ is observed. As it was mentioned before, $\mathrm{TrV}$ replicates within the cytoplasm of gut cells, therefore, method 2 could be potentially more sensitive than any other method in which the complete insect bodies are used. Consequently, this testing method for viral infection would be useful during the early infection stages as well as in the initial triatomines nymphal instars.
In method 3, samples are prepared from fresh feces obtained by abdominal compression of alive hosts (see Material and Methods). In Fig. 3 the virus obtained from five NV is observed. The sensitiveness of this procedure is plainly shown in this micrograph, in which viral particles are clearly distinguished among other amorphous gut contents.

In method 4, the sample is prepared with dry excrement fixed to the paper fans inside the insect containers (see Material and Methods). The observation of a sample prepared with five "buttons" of NIV of T. Infestans are shown in Fig. 4. As in the previous example, this method is quite sensitive and the viral particles are apparent in the electron micrographs.

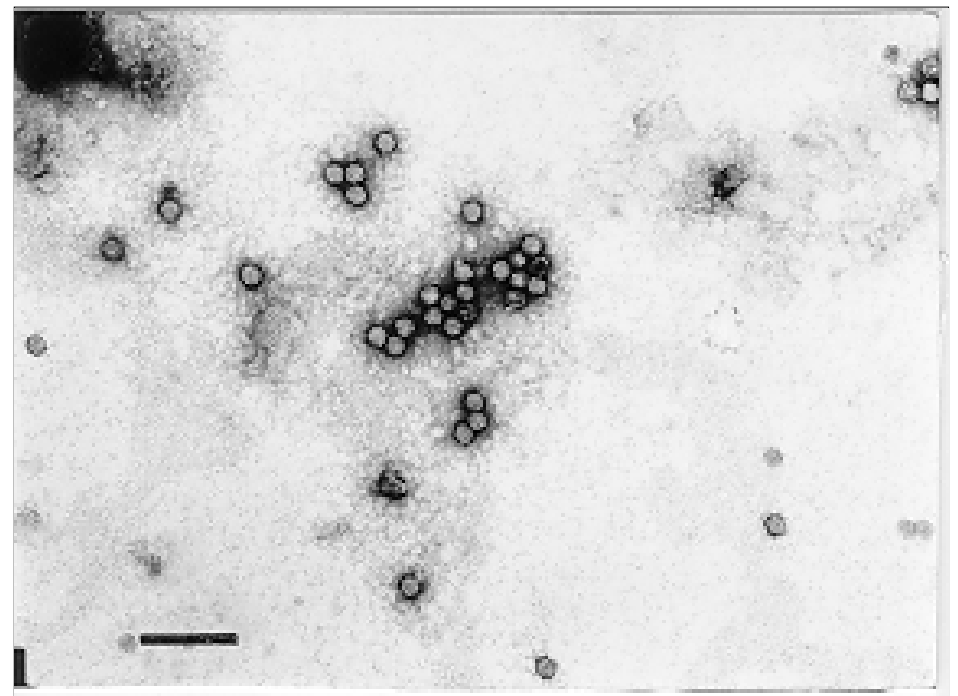

Fig. 1: electron micrograph of Triatoma virus obtained from ten T. infestans female dead insects (see Method 1). TEM x $80,000$. Bar $=150 \mathrm{~nm}$.

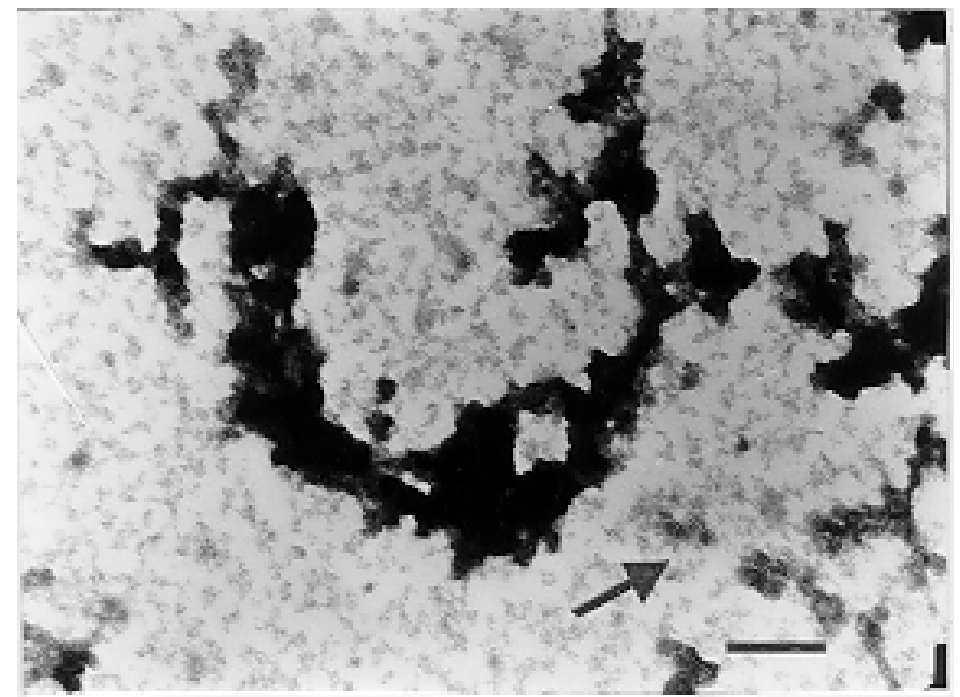

Fig. 2: electron micrograph of Triatoma virus obtained from abdominal contents of NV T. infestans dead insects (see Method 2). The arrow indicates viral particles. TEM x 80,000. Bar $=150 \mathrm{~nm}$. 


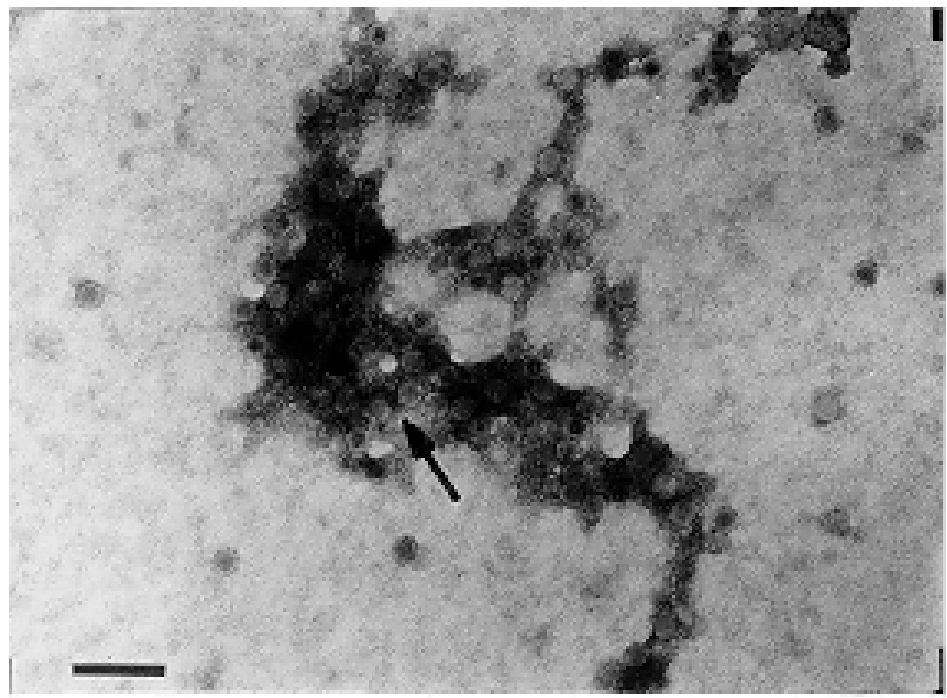

Fig. 3: electron micrograph of Triatoma virus obtained from alive NV T. infestans fresh feces (see Method 3).The arrow indicates viral particles. TEM X 100,000. Bar $=100 \mathrm{~nm}$.

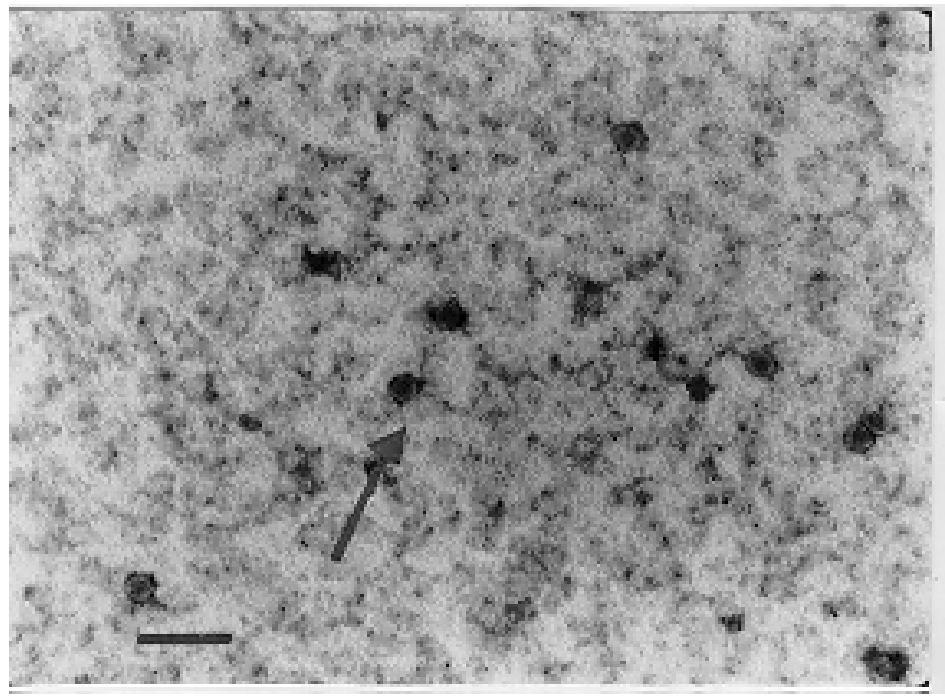

Fig. 4: electron micrograph of Triatoma virus obtained from NIV T. infestans dry button feces (see Method 4).The arrow indicates viral particles. TEM x 100,000. Bar $=100 \mathrm{~nm}$.

Methods 3 and 4 are harmless for the insects, thus a continuous checking control of the infection evaluation may be carried out. On the other hand with method 4, viral particles can be seen even two weeks after insects defecation (data not shown). Therefore, the period while TrV remains intact in feces under natural conditions might be estimated.

The techniques proposed in this work could be used with different purposes in studies intended for detecting virus infection, quantifying and checking virus integrity as well. Furthermore, at least the quick and simple methods such as 2,3 or
4 could be very helpful if they were incorporated as common routines in insectaries.

\section{ACKNOWLEDGEMENTS}

To Dr O Fernández of Centro de Recursos Renovables de la Zona Semiárida for his encouragement throughout this work; to D Canale of Servicio Nacional de Lucha contra el Chagas, Córdoba, Argentina, for the gift of T. infestans colonies and to Lic V Lozano of Centro Regional de Investigaciones Básicas y Aplicadas de Bahía Blanca, for helping us with the electron microscope. During this work GSRD was a fellow of the Comisión de Investigaciones Científicas de la Provincia de Buenos Aires. JLLT, OAM and DMAG are members 
of the Consejo Nacional de Investigaciones Científicas y Técnicas, Argentina.

\section{REFERENCES}

Adams JR, Bonami JR 1991. Preparation of invertebrate virus and tissues for examination. In JR Adams \& JR Bonami (eds), Atlas of Invertebrate Viruses, CRC Press, Boca Raton, p. 9-30.

Evans HF 1986. Ecology and epizoology of baculoviruses. In RR Granados \& BA Federic (eds), Biology in Baculoviruses, Vol. 2, Practical Application for Insect Pest Control, CRC Press, Boca Raton, p. 89-132.

Evans HF, Shapiro M 1997. Viruses. In LA Lacey, Manual of Thechniques in Insect Pathology (Biological Techniques), Academic Press Ltd., p. 17-53.

Mathews REF 1982. Classification and nomenclature of viruses. Intervirology 17: 1-200.

Moore NF, King LA, Posse RD 1987. Viruses of insects. Insect Sci Applic 8: 275-289.

Muscio OA 1988. Búsqueda de Entomopatógenos y su Evaluación como Posibles Agentes de Control de Triatoma infestans, PhD Thesis, Universidad Nacional de La Plata, p. 83-117.

Muscio OA, La Torre JL, Bonder M, Scodeller E 1997. Triatoma virus pathogenicity in laboratory colonies of Triatoma infestans (Hemiptera: Reduviidae). $J$ Med Entomol 34: 253-256.

Muscio OA, La Torre JL, Scodeller EA 1987. Small nonoccluded viruses from triatomine bug Triatoma infestans (Hemiptera, Reduviidae). J Invertebrate Pathol 49: 218-220.
Muscio OA, La Torre JL, Scodeller EA 1988. Characterization of Triatoma virus, a Picorna-like virus isolated from the triatomine bug Triatoma infestans. $J$ Gen Virol 69: 2929-2934.

Rozas Dennis GS, Cazzaniga NJ 1997. Triatominos de Bahía Blanca: Respuestas biológicas a la infección con un Picornavirus. Medicina 57 (Supl. III): 85.

Rozas Dennis GS, Cazzaniga NJ, La Torre JL 1997a. Respuestas biológicas a la infección con Triatoma virus (TrV) en cepas de Triatoma infestans. XII Congreso Latinoamericano de Parasitología, La Habana, Cuba, p. 67.

Rozas Dennis GS, Cazzaniga NJ, La Torre JL 1997b. Susceptibilidad de Triatoma guasayana (Hemiptera: Reduviidae) al virus TrV. XII Congreso Latinoamericano de Parasitología, La Habana, Cuba, p. 52.

Schaub GA, Böker CA, Jensen C, Reduth D 1989. Cannibalism and coprophagy are modes of transmission of Blastocrithidia triatomae (Trypanosomatidae) between triatomines. J Protozool 36: 171- 175.

Schofield CJ, Dolling W 1993. Bed bugs and kissingbugs (blood sucking Hemiptera). In R Lane \& R Crosskey (eds), Medical Insects and Arachnids, The Natural History Museum, London, p. 483-516.

Tompkins GJ 1991. Purification of invertebrate viruses. In Adams JR \& Bonami JR (eds), Atlas of Invertebrate Viruses, CRC Press, Boca Raton, p. 31-40.

WHO Division of Control of Tropical Diseases 1999. URL: http://www.who.int/ ctd/html/chagepidat.html

Zeledon R, Rabinovich JE 1981. Chagas' disease: an ecological appraisal with special emphasis on its insect vectors. Ann Rev Entomol 26: 101-133. 